\title{
Partial Purification and Properties of Acetolactate Synthase of Etiolated Pea Seedlings*
}

\author{
Tsutomu Shimizu, Ishizue Nakayama, Tohru Nakao \\ and Hiroshi ABE \\ Life Science Research Institute, Kumiai Chemical Industry Co., Ltd., \\ Ogasa-gun, Shizuoka 439, Japan
}

(Received November 27, 1993; Accepted March 18, 1994)

\begin{abstract}
Two molecular species of ALS were found in etiolated pea seedlings on gel filtration column chromatography. Molecular weight of these two ALS were approximately 320,000 and 120,000 , respectively. Higher molecular weight species designated large ALS was sensitive to the feedback inhibition by Leu/Val combination, while lower molecular species designated small ALS was insensitive. Large ALS which was fractionated by gel filtration column chromatography produced small ALS during the further chromatography of the same column. $\mathrm{Km}$ value for pyruvate and sensitivity to the feedback inhibition of large ALS were similar to that of the crude enzyme preparation. Both molecular species were sensitive to the inhibition by ALS-inhibiting herbicides. From these results, large ALS is considered to be the native enzyme in etiolated pea seedlings and to change to small ALS by loss of the regulatory center(s) during purification. This ALS showed the following enzymatical properties which had not been reported yet or were making a contrast to those in preceding papers. The rate of acetolactate production did not show a sigmoidal relationship with pyruvate concentration. Negative cooperativities were observed in the inhibition of ALS by leucine, valine and isoleucine. In contrast to Leu/Val combination and Leu/Ile combination, the antagonistic effect was found in the inhibition by Val/Ile combination. The inhibition type of Leu/Val combination varied depending on pyruvate concentration. The inhibitions by leucine or Leu/Val combination were desensitized by neither SH-inhibitors nor ATP.
\end{abstract}

\section{INTRODUCTION}

Acetolactate synthase (ALS; EC 4.1.3.8, also referred as acetohydroxyacid synthase; AHAS) catalyzes the first common step in the biosynthesis of branched-chain amino acids; leucine, valine and isoleucine. The enzyme catalyzes both the formation of acetolactate from two molecules of pyruvate and the formation of acetohydroxybutylate from pyruvate and 2-oxobutylate.

ALS has been found in bacteria, ${ }^{1-4)}$ fungi, ${ }^{5-8)}$ algae $^{9,10)}$ and plants. In recent years, plant ALS has been studied intensively from the

* Action Mechanism of Herbicides, Pyrimidinylsalicylic Acids (Part II). For Part I, see Ref. 22). reason that three structurally unrelated classes of herbicides, namely sulfonylureas, imidazolinones and triazolopyrimidine sulfonamides, inhibit the enzyme. ${ }^{11-13)}$ The enzyme has been shown to exist in chloroplast of matured leaves. ${ }^{14,15)}$ Various molecular species have been reported until now, ${ }^{16-19)}$ though the molecular weight of the protomer, which has the catalytic center, has been shown to be similar to that of the large subunit of enterobacteria. ${ }^{20)}$ There is, however, no definite evidence as to the regulatory subunit(s) as in the case of fungal ALS. Plant ALS is inhibited by Leu/Val combination in a concerted manner that differs from those of microbial ALS. ${ }^{21)}$

In our preceding paper, we have demonstrated that pyrimidinylsalicylic acid (PS) 
compounds* represented by pyrithiobac-sodium (trade name: Staple) inhibit plant ALS potently and should be classified as the fourth ALS inhibitors distinct from the above three types of herbicides. ${ }^{22}$ Therefore, we have examined properties of ALS of etiolated pea seedlings in detail before studying inhibition kinetics of plant ALS by PC herbicides and fcund some new results. In the present paper, we show newly detected molecular species and newly verified enzymatical properties of ALS of etiolated pea seedlings in connection with other ALS-related enzymes such as pyruvate decarboxylase, acetolactate decarboxylase and pyruvate dehydrogenase in etiolated seedling and germinated seeds of pea.

\section{MATERIALS AND METHODS}

\section{Chemicals}

2-(4,6-Dimethoxypyrimidine-2-yloxy)benzoic acid (abbreviated as DOB) which is one of pyrimidinylsalicylic acid compounds in $\mathrm{PC}$ herbicides and imazabenz which is one of imidazolinone type ALS inhibitors used in this study were synthesized at K-I Chemical Research Institute Co., Ltd. (Shizuoka, Japan).

\section{Preparation of Crude Enzyme}

Crude enzymes containing ALS were prepared from etiolated shoots and germinated seeds of pea (Pisum sativum, cv. Akabanatsurunashi) by the method reported previously. ${ }^{22)}$

\section{Purification of ALS from Etiolated Pea Seedlings}

ALS was extracted from 5- to 7-day-old etiolated pea shoots which were grown under dark at $27^{\circ} \mathrm{C}$. The shoots were homogenized in twice volumes of $100 \mathrm{~mm}$ potassium phosphate buffer ( $\mathrm{pH} 7.5)$ containing 20\% (v/v) glycerol, $0.5 \mathrm{~mm}$ thiamine pyrophosphate (TPP), $10 \mu \mathrm{M}$ flavin adenine dinucleotide (FAD), $0.5 \mathrm{~mm} \mathrm{MgCl}_{2}$ and $0.5 \mathrm{~mm}$ dithiothreitol (DTT) (extraction buffer). The homo-

* Pyrimidinylsalicylic acid (PS) compounds form one herbicides group in a new class of herbicides designated "pyrimidinyl carboxy herbicides (PC herbicides)." PC herbicides include not only PS compounds but also other pyrimidinyl oxy (thio) aromatic or heterocyclic carboxylic acid compounds. genate was squeezed through two layers of nylon gauze and centrifuged at $15,000 \times \boldsymbol{g}$ for 20 min. The supernatant was brought to $25 \%$ saturation with ammonium sulfate. After centrifugation, ammonium sulfate was added to the supernatant to give $50 \%$ saturation. The precipitate after centrifugation was dissolved in $10 \mathrm{~mm}$ Tris- $\mathrm{HCl}$ buffer $(\mathrm{pH} \mathrm{7.8)}$ containing $20 \%(\mathrm{v} / \mathrm{v})$ glycerol, $0.5 \mathrm{~mm}$ TPP, 0.5 $\mathrm{mm} \mathrm{MgCl}_{2}$ and $0.5 \mathrm{~mm}$ DTT. The enzyme solution was applied on Sephadex G-25 column equilibrated with the same buffer. The effluent was passed over DEAE-Toyopearl column equilibrated with the same buffer. The column was washed with the same buffer containing $0.1 \mathrm{M} \mathrm{KCl}$, and then the enzyme was eluted with the same buffer of a linear gradient of $\mathrm{KCl}$ between 0.1 and $0.3 \mathrm{M}$. Active fractions were collected and applied on Sephadex G-25 column equilibrated with $10 \mathrm{~mm}$ potassium phosphate buffer $(\mathrm{pH}$ 7.2) containing the same additives as the extraction buffer. The column was washed with the same buffer and the enzyme was eluted with the same buffer of a linear gradient of potassium phosphate buffer ( $\mathrm{pH} 7.2$ ) between 10 to 200 mm. Active fractions were collected and concentrated using ultrafiltration. The concentrated enzyme solution was then applied on Cellulofine GCL-2000 sf gel filtration column equilibrated with the extraction buffer and the enzyme was eluted with the same buffer.

Leucine-Sepharose 4B affinity column chromatography was also conducted after DEAEToyopearl column chromatography. To the active fraction collected after DEAE-Toyopearl chromatography, $0.9 \mathrm{~m}$ (final concentration) of ammonium sulfate was added and the solution was applied on Leucine-Sepharose 4B column equilibrated with $20 \mathrm{~mm}$ potassium phosphate buffer ( $\mathrm{pH}$ 7.5) containing $20 \%$ glycerol, $0.5 \mathrm{~mm}$ TPP, $10 \mu \mathrm{M} \mathrm{FAD}, 0.5 \mathrm{~mm}$ $\mathrm{MgCl}_{2}$ and $0.8 \mathrm{M}$ ammonium sulfate. The column was washed with the same buffer and the enzyme was eluted with $10 \mathrm{~mm}$ Tris- $\mathrm{HCl}$ (pH 7.8) containing the same additives as the extraction buffer. All operations described above were carried out at 0 to $4^{\circ} \mathrm{C}$.

\section{Assay of Acetolactate Synthase}

The reaction mixture $(1 \mathrm{ml})$ consisted of 20 
mu potassium phosphate buffer ( $\mathrm{pH} 7.5), 20$ mu sodium pyruvate, $0.5 \mathrm{~mm}$ TPP, $0.5 \mathrm{~mm}$ $\mathrm{MgCl}_{2}, 10 \mu \mathrm{M} \mathrm{FAD}$, unless otherwise stated. Assays were initiated by adding $200 \mu \mathrm{l}$ of the enzyme solution and terminated after $40 \mathrm{~min}$ incubation at $30^{\circ} \mathrm{C}$ by the addition of $100 \mu \mathrm{l}$ of $6 \mathrm{~N} \mathrm{H}_{2} \mathrm{SO}_{4}$. The amount of acetolactate produced by the enzyme reaction was determined as described previously. ${ }^{22}$

\section{Protein Determination}

Protein concentration was determined by Bradford method ${ }^{23)}$ in accordance with the protocol supplied by the manufacturer (Bio Rad, Richmond, CA, U.S.A.).

\section{Determination of Molecular Weight}

Protein Molecular Weight Standards kit MS II (SERVA Feinbiochemica) and thyrogloblin were used to determine molecular weight of ALS. These proteins were dissolved in the extraction buffer and applied on Cellulofine GCL-2000 sf column equilibrated with the same buffer. The proteins were eluted with the same buffer and determined by the method described above.

7. Assay of the Acetoin Forming Activity and Pyruvate Decarboxylase (EC 4.1.1.1)

The acetoin forming enzyme and pyruvate decarboxylase were assayed in accordance with the method described previously. ${ }^{22)}$

\section{Assay of Decarboxylation Activity of Aceto- lactate (Acetolactate Decarboxylase)}

The reaction mixture $(1 \mathrm{ml})$ consisted of $20 \mathrm{~mm}$ potassium phosphate buffer $(\mathrm{pH} 7.5)$, $0.112 \mathrm{~mm} \alpha$-acetolactate and the enzyme. $\alpha$ Acetolactate was prepared from methylacetoxyethylacetoacetate by the method of Krampitz. ${ }^{24)}$ The assay was initiated by adding enzyme and terminated after incubation for appropriate periods at $30^{\circ} \mathrm{C}$ by $2.5 \mathrm{~N}$ $\mathrm{NaOH}$. Acetoin produced was determined by the method of the ALS assay described above.

\section{Assay of Pyruvate Dehydrogenase}

Pyruvate dehydrogenase was assayed by the method of Reed \& Willms. ${ }^{25}$ The assay mixture $(1.4 \mathrm{ml})$ consisted of $100 \mathrm{~mm}$ potassium phosphate buffer ( $\mathrm{pH}$ 6.0), $36 \mathrm{~mm}$ sodium pyruvate, $0.14 \mathrm{~mm}$ TPP, $0.21 \mathrm{~mm} \mathrm{MgCl}_{2}, 18$ $\mathrm{mu}$ potassium ferricianide and enzyme. The assay was initiated by adding enzyme and terminated after $30 \mathrm{~min}$ incubation at $30^{\circ} \mathrm{C}$ by addition of $1 \mathrm{ml}$ of $10 \%$ trichloroacetic acid (TCA). Denatured proteins were removed by centrifugation. To $0.2 \mathrm{ml}$ of the supernatant, $1 \mathrm{ml}$ of $10 \%$ TCA and $0.1 \mathrm{ml}$ of $0.25 \mathrm{~m}$ potassium ferricianide were added and the solution was filled up to $2.4 \mathrm{ml}$. To the solution, $1 \mathrm{ml}$ of $4 \%$ SDS and $0.5 \mathrm{ml}$ of ferric sulfate ammonium reagent were added. After the solution was stood for $30 \mathrm{~min}$ at room temperature, absorbance at $540 \mathrm{~nm}$ was measured.

\section{RESULTS}

\section{Identification and Characterization of Two Molecular Species of ALS}

No multiple molecular species were found on DEAE-Toyopearl column chromatography, while a possibility of existence of multiple species was obtained with hydroxyapatite column chromatography of Bio-Gel HTP (data not shown). Cellulofine GCL-2000 sf gel filtration column chromatography yielded two peaks of activity (Fig. 1). The molecular weights of those two molecular species were estimated to be approximately 320,000 and 120,000 , respectively, by gel filtration column chromatography (Fig. 1). The properties of the two molecular species were significantly different as follows. The higher molecular weight species designated large ALS was sensitive to the inhibition by leucine or Leu/Val combination as in the case of ALS of crude enzyme (crude ALS). The lower molecular weight species designated small ALS was, however, almost completely insensitive to the inhibition by leucine or Leu/Val combination (Fig. 2, Table 1). On the other hand, both molecular species were sensitive to the inhibition by ALS-inhibiting herbicides such as DOB and imazabenz (Fig. 3). $K m$ value for pyruvate of small ALS was approximately three times larger than those of large ALS. $\mathrm{Km}$ values of large ALS and the crude ALS were nearly identical (Table 1). The sensitivities of ALS to the inhibition by leucine or Leu/Val combination decreased during purification steps (Table 2). Large ALS which was fractionated by gel filtration column chromatog- 


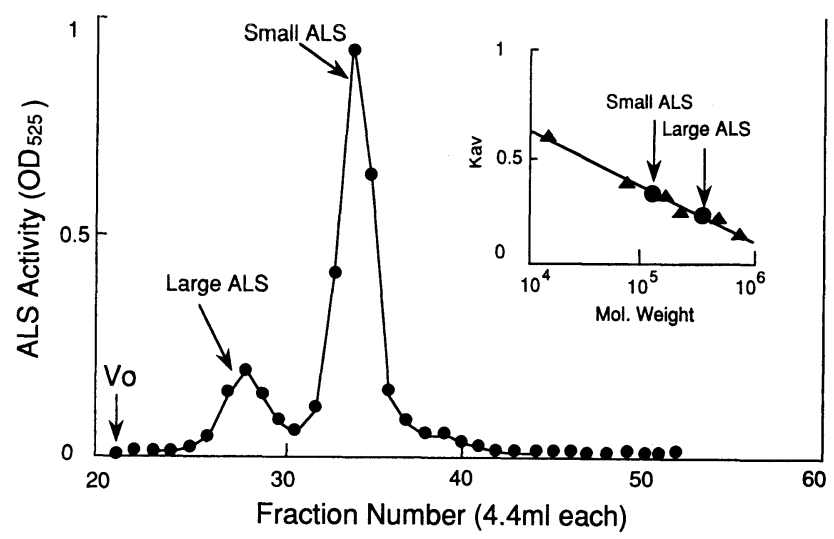

Fig. 1 Elution profile of acetolactate synthase from pea etiolated seedlings on Cellulofine GCL-2000 sf gel filtration column chromatography and molecular weight determination of two molecular species of acetolactate synthase.

Cytochrome $c(12,300)$, albumin $(67,000)$, aldolase $(160,000)$, catalase $(240,000)$, ferritin $(450,000)$ and thyrogloblin $(660,000)$ were used to determine molecular weight of ALS.

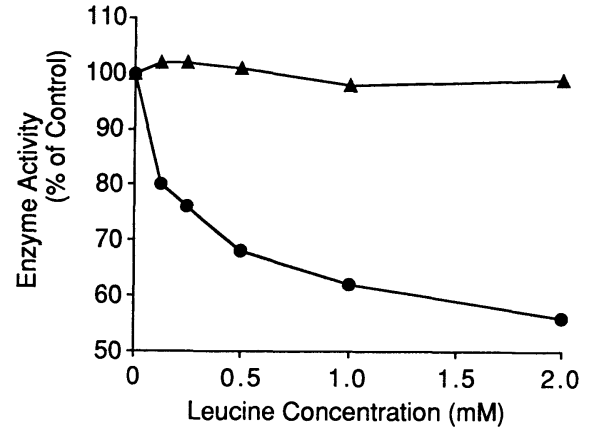

Fig. 2 Sensitivities of both higher molecular weight species (large ALS) and lower molecular weight species (small ALS) of acetolactate synthase to the inhibition by leucine.

๑: large ALS, $\boldsymbol{\Delta}$ : small ALS.

Table 1 Properties of acetolactate synthase from etiolated pea seedlings.

\begin{tabular}{|c|c|c|c|}
\hline \multirow{2}{*}{ Enzyme form } & \multicolumn{2}{|c|}{$K m$ at $\mathrm{pH} 7.5$} & \multirow{2}{*}{$\begin{array}{c}\text { Inhibition } \\
(\%)^{c)}\end{array}$} \\
\hline & $\underset{\left.(\mathrm{mM})^{\mathrm{a}}\right)}{\mathrm{Pyr}}$ & $\begin{array}{c}\text { TPP } \\
(\mu \mathrm{M})^{\mathrm{b})}\end{array}$ & \\
\hline Crude ALS & $1.5 \pm 0.1$ & $9.6 \pm 2.1$ & 60 \\
\hline Large ALS & $1.6 \pm 0.2$ & - & 47 \\
\hline Small ALS & $3.0 \pm 0.6$ & - & 5 \\
\hline
\end{tabular}

a) $K m$ value for pyruvate.

b) $K m$ value for thiamine pyrophosphate.

c) ALS Inhibition percentage by Leu/Val combination ( $2 \mathrm{~mm}$ each) at $20 \mathrm{~mm}$ of pyruvate concentration.

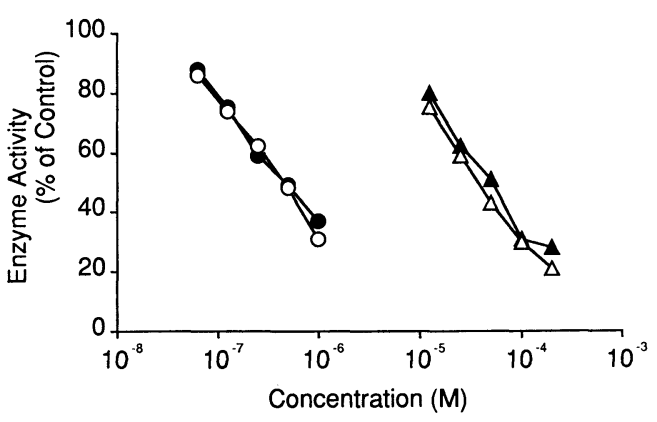

Fig. 3 Sensitivities of both higher molecular weight species (large ALS) and lower molecular weight species of acetolactate synthase (small ALS) to the inhibition by ALS-inhibiting herbicides.

-: large ALS with DOB, $\bigcirc$ : small ALS with DOB, $\Delta$ : large ALS with imazabenz, $\triangle$ : small ALS with imazabenz.

raphy produced small ALS during further chromatography of the same column (Fig. 4). Two molecular species were also identified on Leucine-Sepharose 4B affinity column chromatography. One species which was not adsorbed on the column was insensitive to the inhibition by leucine and the other which was adsorbed on the column was sensitive (data not shown). Overall purification folds of large ALS and small ALS were 26 and 103, respectively (Table 3). 
Table 2 The changes in the level of maximum inhibition (M.I), ${ }^{\text {a) }} I_{50}$, ${ }^{\text {b) }}$ and $M_{50}$ c) during purification.

\begin{tabular}{|c|c|c|c|c|c|c|c|c|c|}
\hline \multirow{2}{*}{ Fraction } & \multicolumn{3}{|c|}{ Leu $^{\mathrm{d})}$} & \multicolumn{3}{|c|}{ Vale) } & \multicolumn{3}{|c|}{ Leu +Val (1: 1) } \\
\hline & $\begin{array}{l}\text { M.I } \\
(\%)\end{array}$ & $\begin{array}{c}\mathrm{I}_{50} \\
(\mathrm{mM})\end{array}$ & $\underset{(\mathrm{mM})}{\mathrm{M}_{50}}$ & $\begin{array}{l}\text { M.I } \\
(\%)\end{array}$ & $\underset{(\mathrm{mM})}{\mathrm{I}_{50}}$ & $\underset{(\mathrm{mM})}{\mathrm{M}_{50}}$ & $\begin{array}{l}\text { M.I } \\
(\%)\end{array}$ & $\underset{(\mathrm{mM})}{\mathrm{I}_{50}}$ & $\begin{array}{c}\mathrm{M}_{50} \\
(\mathrm{mM})\end{array}$ \\
\hline $\left.\operatorname{AmS}(25-55 \%)^{\mathrm{f}}\right)$ & 79 & 0.16 & 0.10 & 83 & 0.30 & 0.25 & 92 & 0.025 & 0.014 \\
\hline DEAE-Toyopearl & 69 & 0.73 & 0.23 & 64 & 2.75 & 0.24 & 80 & 0.035 & 0.020 \\
\hline Bio-Gel HTP & 54 & 1.6 & 0.18 & 59 & 6.9 & 0.55 & 69 & 0.056 & 0.020 \\
\hline
\end{tabular}

a) Maximum inhibition obtained at $2 \mathrm{~mm}$ of pyruvate concentration.

b) The concentration required for $50 \%$ inhibition of ALS activity at $2 \mathrm{~mm}$ of pyruvate concentration.

e) The concentration required for $50 \%$ of maximum inhibition of ALS activity at 2 mm of pyruvate concentration.

d) L-Leucine.

e) L-Valine.

) Ammonium sulfate.
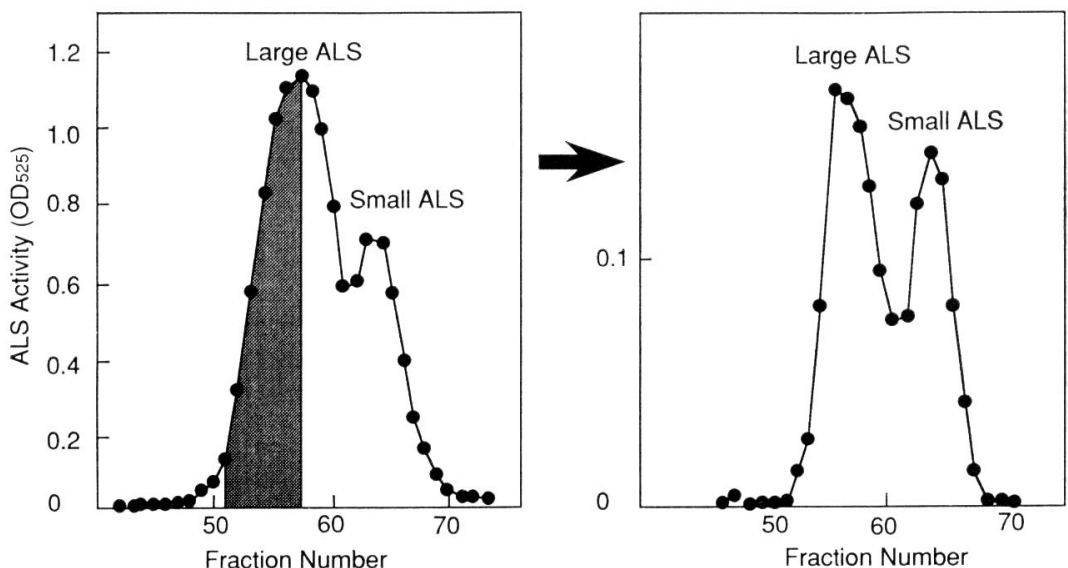

Fig. 4 Regeneration of lower molecular weight species (small ALS) from higher molecular weight species (large ALS) during Cellulofine GCL-2000 sf gel filtration column chromatography. Large ALS obtained by the first chromatography (the shaded portion of the left figure) was re-chromatographed.

Table 3 Purification of acetolactate synthase from etiolated pea seedlings. ${ }^{a)}$

\begin{tabular}{lccccc}
\hline \multicolumn{1}{c}{ Step } & $\begin{array}{c}\text { Protein } \\
(\mathrm{mg})\end{array}$ & $\begin{array}{c}\text { Total activity } \\
\text { (unit) }\end{array}$ & $\begin{array}{c}\text { Specific activity } \\
\text { (unit/mg) }\end{array}$ & $\begin{array}{c}\text { Yield } \\
(\%)\end{array}$ & Fold \\
\hline Crude extract & 6653 & 303 & 0.046 & - & - \\
AmS (25-55\%) ${ }^{\mathrm{c}}$ ) & 3266 & 189 & 0.058 & 62 & 1.3 \\
DEAE-Toyopearl & 134 & 64.5 & 0.481 & 21 & $\mathbf{1 1}$ \\
Bio-Gel HTP & 10.8 & 13.5 & 1.25 & & 27 \\
Cellulofine GCL-2000 sf & & & & 0.21 & 26 \\
$\quad$ Large ALS & 0.54 & 0.65 & 1.20 & 0.38 & 103 \\
Small ALS & 0.24 & 1.14 & 4.75 & & \\
\hline
\end{tabular}

a) $730 \mathrm{~g}$ of seedlings were used for the experiment.

b) Unit is defined as $\mu \mathrm{mol}$ of acetoin produced per hour at $30^{\circ} \mathrm{C}$.

c) Ammonium sulfate fractionation. 


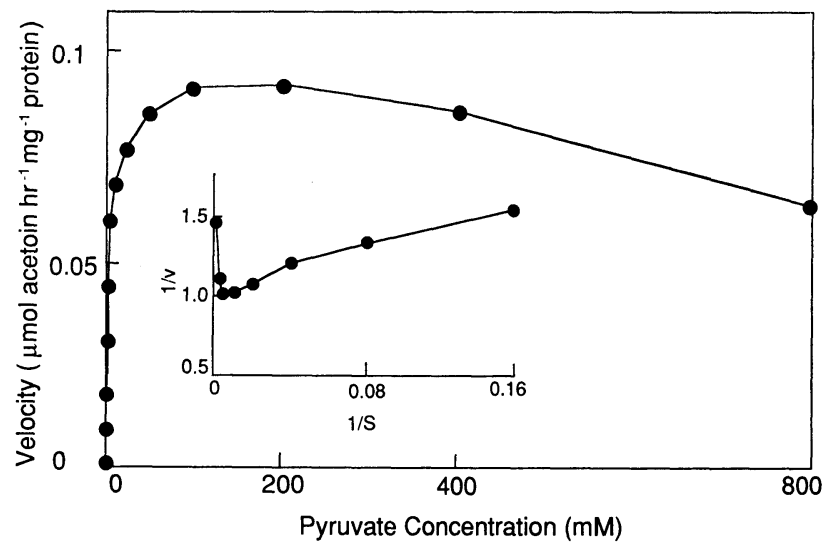

Fig. 5 Effect of pyruvate concentration on the rate of acetolactate production by acetolactate synthase from pea etiolated seedlings.

(A)

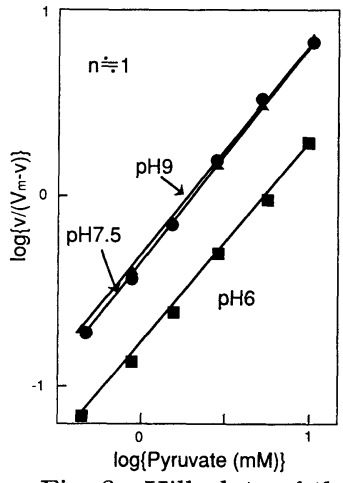

(B)

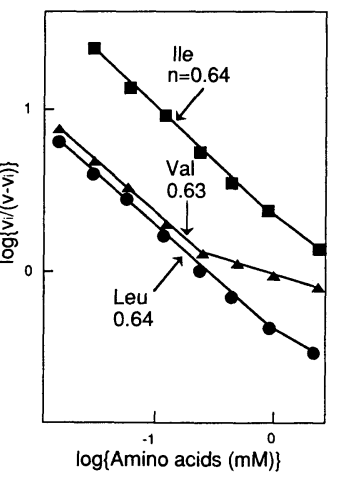

Fig. 6 Hill plots of the rate of acetolactate production $v s$. substrate concentration (A) and $v s$. branched-chain amino acids concentration (B).

2. Properties of ALS of Etiolated Pea Seedlings 2.1 Effect of pyruvate and TPP on ALS activity

The pyruvate saturation curves of the crude ALS was hyperbolic. At high pyruvate concentration substrate promotion and inhibition were observed (Fig. 5). $K m$ value for pyruvate depended on assay $\mathrm{pH}$ and the values of $1.5 \pm 0.1 \mathrm{~mm}$ at $\mathrm{pH} 7.5,5.7$ at $\mathrm{pH} 6$ and 2.0 at $\mathrm{pH} 9$ were obtained from Lineweaver-Burk plots with pyruvate concentration varying between 2 and $10 \mathrm{~mm}$, while $\mathrm{Km}$ value for TPP was $9.6 \pm 2.1 \mu \mathrm{M}$ at $\mathrm{pH} 7.5$ with TPP concentration varying between 0.0125 and $0.4 \mathrm{~mm}$ (Table 1). Hill coefficient of pyruvate was approximately 1 , which was

independent on pyruvate concentration and $\mathrm{pH}$ value (Fig. 6).

\section{2 pH optima}

Optimum $\mathrm{pH}$ of the crude ALS depended on pyruvate concentration. Approximately 6.5 was obtained at high pyruvate concentration (100 mm), while approximately 8 was at low pyruvate concentration (1 mm) (Fig. 7). Similar results were found with both the active fraction after DEAE-Toyopearl column chromatography and Bio-Gel HTP hydroxyapatite column chromatography, though slopes of the parabolic curves were steeper than that of the crude ALS at alkaline sites (data not shown).

\subsection{ALS inhibition by branched-chain amino acids}

The degree of the inhibition of the crude ALS by leucine, valine and isoleucine was different. Leucine was the most effective inhibitor among them. The inhibitions by Leu/ Val combination and Leu/Ile combination were greater than those by leucine, valine and isoleucine alone. The synergistic inhibitions were found at low leucine concentration with constant concentrations of either valine or isoleucine (Fig. 8A). A similar result was obtained at low valine concentration with constant isoleucine concentration. The antagonistic effect, however, was observed with Val/Ile combination (Fig. 8B). Inhibitions by those three amino acids were partially competitive with respect to pyruvate at the concentration varying between 2 and $10 \mathrm{~mm}$ (Fig. 9). Leu/Val combination (1:1 molar 


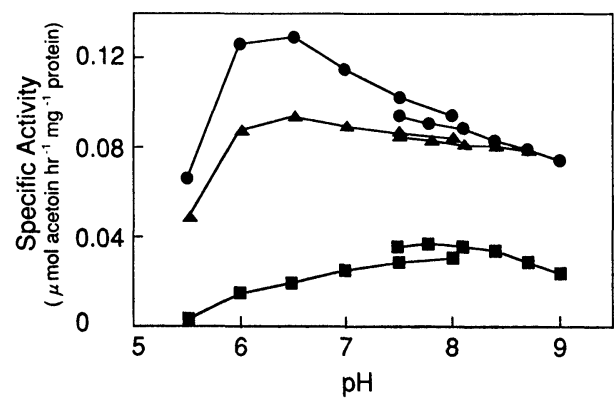

Fig. $7 \mathrm{pH}$ dependency of acetolactate synthase from pea etiolated seedlings with variable pyruvate concentration.

: $100 \mathrm{~mm}$ pyruvate, $\boldsymbol{\Delta}: 20 \mathrm{~mm}$ pyruvate, $1 \mathrm{~mm}$ pyruvate.

(A)

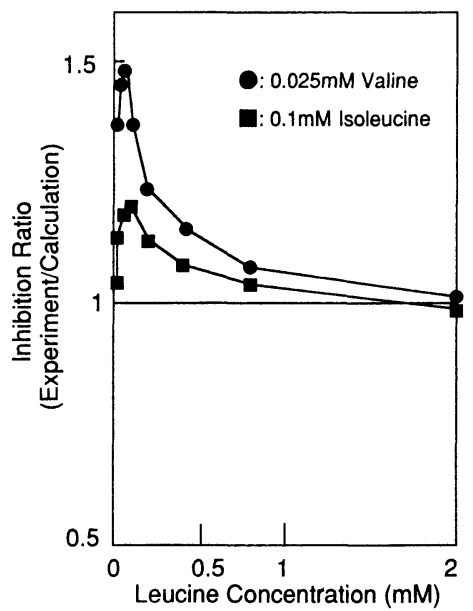

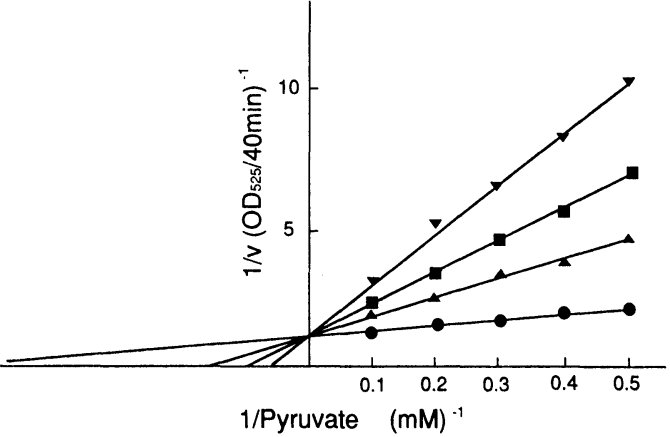

Fig. 9 Lineweaver-Burk plots of the inhibitions of acetolactate synthase from pea etiolated seedlings by each branched-chain amino acid with pyruvate concentration varying between 2 and $10 \mathrm{~mm}$.

- : Control, $\boldsymbol{\Delta}$ : $5 \mathrm{~mm}$ isoleucine, $\boldsymbol{\nabla}: 5 \mathrm{~mm}$ leucine.

(B)

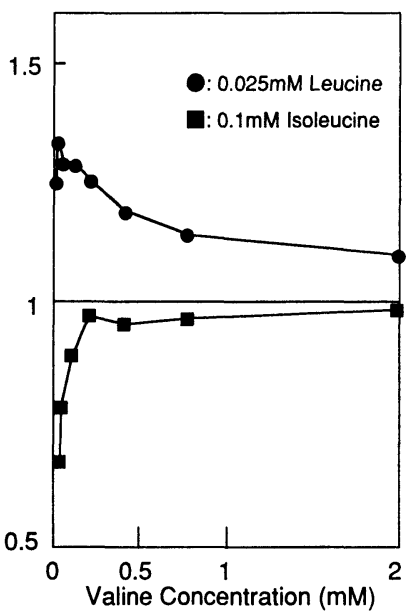

Fig. 8 Variation of synergistic and antagonistic inhibitions of acetolactate synthase from pea etiolated seedlings by branched-chain amino acids.

Inhibition ratio was expressed as the ratio of the inhibition percentage which was obtained experimentally by paired amino acids (Experiment) vs. that calculated from below the Gowing's equation.

$$
\text { Calculation }=I_{\mathrm{A}}+I_{\mathrm{B}}\left(1-I_{\mathrm{A}} / 100\right)
$$

where $I_{\mathrm{A}}$ is the inhibition percentage given by one of paired amino acids, and $I_{\mathrm{B}}$ is that by the other of paired amino acids.

In the case of synergistic inhibition the inhibition ratios in the figures become over 1, while in the case of antagonistic inhibition they become below 1 .

ratio) also gave the same inhibition type with the same concentration range of pyruvate, while its inhibition type was nearly non-competitive with pyruvate concentration varying between 0.6 and $2 \mathrm{~mm}$ (Fig. 10). Hill coefficients for the inhibition by each branched- chain amino acid were 0.63 to 0.64 (Fig. 6). The inhibitions by each branched-chain amino acid were $\mathrm{pH}$-dependent. Stronger inhibition by leucine was found at acidic $\mathrm{pH}$ than the alkaline (Table 4). ATP, which is known to desensitize the inhibition of fungal ALS by 


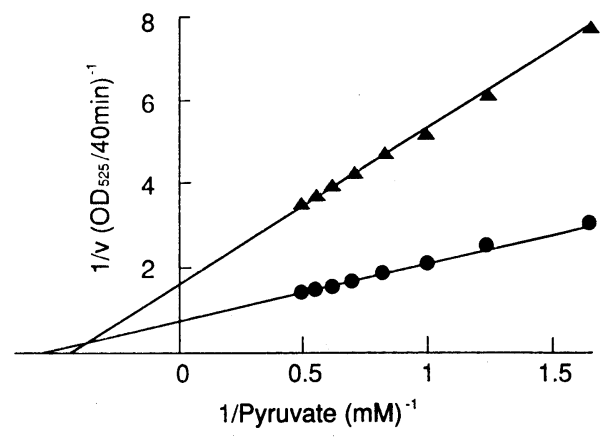

Fig. 10 Lineweaver-Burk plot of the inhibition of acetolactate synthase from pea etiolated seedlings by Leu/Val combination with pyruvate concentration varying between 0.6 and $2 \mathrm{~mm}$.

: control, $\Delta$ : $0.25 \mathrm{~mm}$ leucine plus $0.25 \mathrm{~mm}$ valine.

Table 4 Effect of assay pH, ATP and SHinhibitors on the inhibition of acetolactate synthase from etiolated pea seedlings by branched-chain amino acids.

\begin{tabular}{|c|c|c|c|c|}
\hline \multirow{2}{*}{\multicolumn{2}{|c|}{$\begin{array}{l}\text { Assay pH } \\
\text { and } \\
\text { additives }\end{array}$}} & \multirow{2}{*}{$\begin{array}{l}\text { Relative } \\
\text { activity } \\
(\%)\end{array}$} & \multicolumn{2}{|c|}{ Inhibition ( $\%)$} \\
\hline & & & $\left.\operatorname{Leu}^{a}\right)$ & $\begin{array}{l}\text { Leu }+ \\
\text { Val }^{\text {b) }}\end{array}$ \\
\hline \multirow{5}{*}{$\mathrm{pH}^{\mathrm{e})}$} & 6.0 & 100 & 53 & \\
\hline & 6.5 & 108 & 44 & \\
\hline & 7.0 & 102 & 39 & \\
\hline & 7.5 & 98 & 25 & \\
\hline & 8.0 & 97 & 24 & \\
\hline \multirow{5}{*}{$\begin{array}{l}\text { ATP } \\
(\mathrm{mm})\end{array}$} & 0 & 100 & & 42 \\
\hline & 0.01 & 100 & & 42 \\
\hline & 0.1 & 100 & & 38 \\
\hline & 1 & 100 & & 40 \\
\hline & 2 & 95 & & 40 \\
\hline \multirow{6}{*}{$\begin{array}{l}\mathrm{HgCl}_{2} \\
(\mathrm{~mm})\end{array}$} & 0 & 100 & 41 & \\
\hline & 0.03125 & 95 & 42 & \\
\hline & 0.0625 & 88 & 48 & \\
\hline & 0.125 & 71 & 50 & \\
\hline & 0.25 & 66 & 47 & \\
\hline & 0.5 & 35 & 53 & \\
\hline \multirow{5}{*}{$\begin{array}{l}\mathrm{CuSO}_{4} \\
(\mathrm{~mm})\end{array}$} & 0 & 100 & 42 & \\
\hline & 0.0625 & 93 & 42 & \\
\hline & 0.125 & 88 & 42 & \\
\hline & 0.25 & 71 & 37 & \\
\hline & 0.5 & 50 & 45 & \\
\hline
\end{tabular}

a) L-Leucine $(0.5 \mathrm{~mm})$.

b) L-Leucine plus L-valine pair $(0.1 \mathrm{~mm}$ each).

c) Assayed with $20 \mathrm{~mm}$ of pyruvate. valine, and SH-inhibitors, which inhibited ALS, did not desensitize the inhibitions of ALS by leucine or Leu/Val combination (Table $4)$.

3. Activities of the Acetoin Forming Enzyme, Pyruvate Decarboxylase, Acetolactate Decarboxylase and Pyruvate Dehydrogenase

The ratios of enzyme activities of the direct acetoin formation (the acetoin forming activity) vs. total acetoin production (ALS activity) of the crude ALS and small ALS of etiolated pea seedlings were approximately 0.25 . These apparent activities for the direct acetoin formation were derived from chemical decarboxylation of acetolactate in the alkaline condition at $60^{\circ} \mathrm{C}$ (Fig. 11). On the other hand, the ratio by the crude enzyme of germinated pea seeds was 0.72 , indicating that there was the enzyme activity which produced acetoin directly from pyruvate.

The first order reaction rate constant of chemical decarboxylation of acetolactate at $30^{\circ} \mathrm{C}$ was $4.3 \times 10^{-4} \mathrm{~min}^{-1}$ and was enhanced by the additions of the crude enzyme from neither etiolated seedlings $\left(4.5 \times 10^{-4} \mathrm{~min}^{-1}\right)$ nor germinated seeds of pea $\left(4.2 \times 10^{-4} \mathrm{~min}^{-1}\right)$.

Pyruvate decarboxylase activity in the crude enzyme of germinated pea seeds was $2.2 \mu \mathrm{mol} \mathrm{NADH}$ oxidized $\mathrm{hr}^{-1} \mathrm{mg}^{-1}$ protein, which was rather higher than that $(0.31 \mu \mathrm{mol}$ $\mathrm{NADH}$ oxidized $\mathrm{hr}^{-1} \mathrm{mg}^{-1}$ protein) in the crude enzyme of etiolated pea seedlings.

Pyruvate dehydrogenase activity were not detected in the crude enzyme of etiolated pea seedlings.

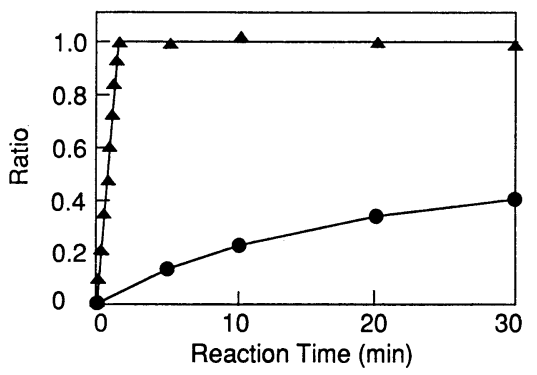

Fig. 11 Time-course of chemical acetoin production from acetolactate in both alkaline and acidic conditions at $60^{\circ} \mathrm{C}$.

Ratio $=$ acetoin produced $/$ acetolactate added . ๑: alkaline condition, $\mathbf{\Delta}$ : acidic condition. 


\section{DISCUSSION}

Multiple molecular species of ALS from eukaryote, which were different forms of a single ALS, were first demonstrated in ALS of Neurospora crassa on gel filtration chromatography. ${ }^{5)}$ The similar different forms of ALS have been shown in monocotyledonous plants such as developing maize kernels, sweet corn cultured cells and etiolated barley seedlings. ${ }^{16-19)}$ Now ALS of those plants are considered to dissociate to lower molecular weight species from the native enzymes in the absence of FAD. ${ }^{19,26)}$

This is the first paper reporting on two different forms of ALS in a dicotyledonous plant, pea. The results described above supported that the higher molecular weight species was the native enzyme and changed to the lower one by loss of the regulatory center(s) during purification. It has been reported that the lower molecular species of ALS from developing maize kernels and barley etiolated seedlings are sensitive to the feedback inhibition, ${ }^{16,19)}$ while that of cultured corn cells are insensitive. ${ }^{17)}$ The properties of small ALS demonstrated in this paper were similar to those of cultured corn cells.

Pea ALS has been characterized with ripening seeds and etiolated seedlings. ${ }^{27,28)}$ Ripening pea seeds contained two distinct ALS which were presumed to be isozymes. The main reasons for this presumption were that optimum $\mathrm{pH}$ varied depending on pyruvate concentration and that $K m$ value for pyruvate changed by assay $\mathrm{pH}$. We obtained, however, the same results as to those properties using crude ALS of etiolated pea seedlings which was considered to contain a single ALS. Hence, not only ALS of pea etiolated seedlings but also ALS of ripening pea seeds are judged to consist of only a single ALS and unusual properties of the enzyme are attributable to those of the oligomeric enzyme which plays a regulatory role in the biosynthetic pathway.

The enzymatical properties of plants ALS have been characterized using ALS of ripening pea seeds, ${ }^{27)}$ etiolated pea seedlings ${ }^{28)}$ and etiolated barley seedlings. ${ }^{21}$ ) We found the following new enzymatical properties of ALS from etiolated pea seedlings. (a) The rate of acetolactate production did not show a sigmoidal relationship with pyruvate concentration. Hill coefficient of pyruvate was approximately 1.0 independently from pyruvate concentration and $\mathrm{pH}$ value. (b) The inhibition by leucine, valine and isoleucine showed negative cooperativities, indicating homotropic allosteric effects in the feedback inhibitions by branched-chain amino acids. (c) In contrast to Leu/Val combination and Leu/Ile combination, the antagonistic effect was found in the inhibition by Val/Ile combination. (d) The inhibition type of Leu/Val combination changed depending on pyruvate concentration. Non-competitive pattern was obtained at low pyruvate concentration. (e) SH-inhibitors and ATP did not desensitize the inhibitions of ALS by leucine or Leu/Val combination.

Our results regarding to the Hill coefficient of pyruvate was contrast to those reported on ALS of etiolated pea seedlings ${ }^{28)}$ and etiolated barley seedlings, ${ }^{21)}$ where positive cooperativities had been shown. The negative cooperativities of the feedback inhibitions and the sensitivities of the inhibition by leucine to $\mathrm{SH}$ reagents found in this paper were also contrast to that reported on barley seedlings. ${ }^{21}$ )

The reason of the difference between our results and those of barley seedlings was surmised to be diversities of ALS among plant species. The results demonstrated in (b), (c) and (d) revealed that the regulatory centers which were located on the allosteric sites in ALS had two kinds of binding sites to branched-chain amino acids. One of those was for leucine and the other for either valine or isoleucine.

A limited activity of pyruvate decarboxylase was detected in the crude enzyme of etiolated pea seedlings, while relatively high activity was detected in that of germinated pea seeds. Direct acetoin productions were found in both the crude enzyme of etiolated seedlings and germinated seeds of pea. But, that of etiolated pea seedlings was due to the chemical decarboxylation of acetolactate which was produced from pyruvate by ALS, while that of germinated pea seeds were attributable to pyruvate decarboxylase which catalyzes the direct acetoin formation by pyruvate as its 
side reaction. ${ }^{22,27)}$ No activities of acetolactate decarboxylase were found in both the crude enzymes of etiolated seedlings and germinated seeds of pea.

From these results, it should be concluded that pea contains only a single ALS which might be composed of the catalytic protomer(s) and the regulatory protomer(s). And its enzymatic properties are considered to be rather different from barley ALS.

Since there were no activities of pyruvate decarboxylase and pyruvate dehydrogenase, which have been mistaken for the ALS activity ${ }^{29,30)}$ in the crude enzyme of etiolated pea seedlings, we can utilize the crude enzyme preparation as well as the purified enzyme for both the detail analysis of ALS inhibition by herbicides and the screening of ALS inhibitors.

\section{ACKNOWLEDGMENTS}

The authors are indebted to Kumiai Chemical Industry Co., Ltd. for permission to publish this work. We are thankful to Mr. K. Sugiyama of K-I Chemical Institute for providing DOB.

\section{REFERENCES}

1) R. C. Wek, C. A. Hauser \& G. W. Hatfield: Nucleic Acids Res. 13, 3995 (1985)

2) J. V. Schloss, D. E. Van Dyk, J. F. Vasta \& R. M. Kutny: Biochemistry 24, 4952 (1985)

3) H. Grimmiger \& H. E. Umbarger: J. Bacteriol. 137, 846 (1979)

4) L. Eoyang \& P. M. Silverman: J. Bacteriol. 157, 184 (1984)

5) L. Glatzer, E. Eakin \& R. P. Wagner: $J$. Bacteriol. 112, 453 (1972)

6) H. Tanaka \& H. Kuwana: Biochem. Biophys. Res. Commun. 123, 418 (1984)

7) S. C. Falco, K. S. Dumas \& K. J. Rivak: Nucleic Acids Res. 13, 4011 (1985)

8) C. Poulsen \& P. Stougaard: Eur. J. Biochem. 185, 433 (1989)

9) Y. Oda, Y. Nakano \& S. Kitaoka: J. Gen. Microbiol. 128, 1211 (1982)

10) D. Landstein, D. M. Chipman, S. M. Arad \& Z. Barak: Plant Physiol. 94, 614 (1990)

11) T. B. Ray: Plant Physiol. 75, 827 (1984)

12) D. L. Shaner, P. C. Anderson \& M. A. Stidham: Plant Physiol. 76, 545 (1984)

13) B. C. Gerwick, M. V. Subramanian, V. I. LoneyGallant \& D. P. Chandler: Pestic. Sci. 29, 357 (1990)

14) B. J. Miflin: Plant Physiol. 54, 550 (1974)

15) D. S. Siebert, D. Heinke, H. Scharf \& G. Scults: Plant Physiol. 76, 465 (1984)
16) M. J. Muhitch: Plant Physiol. 86, 23 (1988)

17) B. K. Singh, M. A. Stidham \& D. L. Shaner: $J$. Chromatogr. 444, 251 (1988)

18) J. Durner \& P. Böger: Z. Naturforsch. 43c, 850 (1988)

19) B. K. Singh \& G. K. Schmitt: FEB.S 258, 113 (1989)

20) B. K. Singh, G. Schmitt, M. Lillis, J. M. Hand \& R. Misra: Plant Physiol. 97, 657 (1991)

21) B. J. Miflin: Arch. Biochem. Biophys. 146, 542 (1971)

22) T. Shimizu, I. Nakayama, T. Nakao, Y. Nezu \& H. Abe: J. Pesticide Sci. 19, 59 (1994)

23) M. Bradford: Anal. Biochem. 72, 248 (1976)

24) L. O. Krampitz: "Methods in Enzymology," ed. by S. P. Colowick \& N. O. Kaplan, Vol. 3, Academic Press, New York, pp. 277-283, 1957

25) L. J. Leed \& C. R. Willms: "Methods in Enzymology," ed. by W. A. Wood, Vol. 9, Academic Press, New York/London, pp. 247265,1966

26) J. Durner \& P. Böger: Plant Physiol. 93, 1027 (1990)

27) M. E. Davis: Plant Physiol. 39, 53 (1964)

28) E. H. Lee, T. W. Ahn \& J. D. Choi: Korean Biochem. J. 24, 285 (1991)

29) M. Nakata: Weed Res. Jpn., 36, 58 (1991)

30) R. W. Harding, D. F. Caroline \& R. P. Wagner: Arch. Biochem. Biophys. 138, 653 (1970)

$$
\text { 要約 }
$$

\section{エンドウ黄化幼植物茎葉からのアセト乳酸シン ターゼの部分精製と性質*}

清水 力, 中山 礎, 中尾 徹, 阿部 洋 エンドウ黄化幼植物茎葉からアセト乳酸シンターゼ (ALS) を精製したところ，分子量の相違する 2 種の ALS が検出されたが，酵素的性質および精製中の挙動 から判断して, 分子量の小さな分子種は大きな分子種か ら制御中心がはずれて生成したものと結論された。した がって，エンドウの ALS は一種でありアイソザイムは 存在しないものと考觉られる.この ALS はこれまでに 報告されていない次のような性質を示した. (1) 基質で ある 2 分子のピルビン酸の間には協同性が認められな い. (2) 分㞳鎖アミノ酸によるフィードバック阻害は負 の協同性を示す. (3) バリンによる阻害とイソロイシン による阻害は拮抗的である. (4) フィードバック阻害の 阻害形式はピルビン酸濃度に依存して変化する. (5) 分 岐鎖アミノ酸によるフィードバック阻害は SH 基阻害 剤やATPにより脱感作されない。

*ピリミジニルサリチル酸系除草剤の作用機構（第 2 報) 